\title{
Experimental Investigation of Performance and Emissions of a Stratified Charge CNG Direct Injection Engine with Turbocharger
}

\author{
Hilmi Amiruddin ${ }^{1,2}$, Wan Mohd Faizal Wan Mahmood ${ }^{1}$, Shahrir Abdullah ${ }^{1}$, Mohd Radzi Mansor ${ }^{1}$ and Mohd Fadzli Abdollah ${ }^{2}$ \\ ${ }^{1}$ Faculty of Engineering and Built Environment, Universiti Kebangsaan Malaysia, 43600 UKM Bangi, Selangor, Malaysia \\ ${ }^{2}$ Faculty of Mechanical Engineering, Universiti Teknikal Malaysia Melaka, Hang Tuah Jaya, 76100 Durian Tunggal, Melaka, Malaysia
}

\begin{abstract}
This paper presents the results from 1.6 litre, 4 cylinders stratified charge compressed natural gas (CNG) direct injection engine with boosting device. A turbocharger with compressor trim of 40 was used to increase engine output. The engine was tested at wide open throttle (WOT) and speed ranging from 1000 to $5000 \mathrm{rpm}$. Engine performance and emissions data were recorded under steady state condition. Results show turbocharged CNG engine produced an average of $26 \%$ increment in brake power and $24 \%$ additional maximum brake torque as compared with natural aspirated (NA) CNG engine. Turbocharged CNG engine improved brake specific fuel consumption (BSFC) and yielded higher fuel conversion efficiency (FCE). Relatively turbocharged CNG engine showed lower emission of hydrocarbon $(\mathrm{HC})$ and carbon monoxide $(\mathrm{CO})$ throughout tested engine speed. Conversely, the carbon dioxide $\left(\mathrm{CO}_{2}\right)$ and nitrogen oxide $\left(\mathrm{NO}_{\mathrm{x}}\right)$ emission produced were slightly higher compared with NA CNG engine.
\end{abstract}

\section{Introduction}

The exhaust gases of vehicles are one of the main contributors to the world's greenhouse gases problem. Quest for alternative fuel for automotive engine has gained more attentions mainly due to stringent emission limit and instability of world liquid fossil fuel price. The use of natural gas as an alternative fuel in spark ignition (SI) direct injection (DI) engine have been studied expansively and utilized in vehicles [1-2].

Higher octane number of natural gas gives several advantages as a fuel for SI engine including suitable for high compression ratio engine operation, higher thermal efficiency and less knocking problem.

Stratified charge engines have rich mixture around spark plug and leaner mixture for the rest of the combustion chamber.

Currently, boosting device technology has been widely used in automotive engine due to increasing demand of engine power output, better fuel economy and reduces emission level [3]. The use of turbocharging technology in gasoline SI engine is limited due to knocking and premature combustion [4]. Nowadays, interest in application of boosting device operating on natural gas engine produced promising results. This is due to higher knocking resistance properties of natural gas and suitable for high compression ratio SI engine [5].

The main objective of this study is to experimentally investigate the stratified charged CNG DI engine with turbocharger output and emission performance.
Tests were conducted on a $1600 \mathrm{~cm}^{3}, 4$ cylinders, spark ignition and direct injection $\mathrm{CNG}$ engine. The arrangement of the engine experimental setup is shown in Figure 1 and the specifications of the engine are listed in Table 1. An eddy current dynamometer (Apicom Model FR250) and KRONOS 4 software were used to program the engine test and recorded all the performance results. The engine was tested at steady state conditions with wide open throttle (WOT) at constant speed ranging from $1000 \mathrm{rpm}$ to $4500 \mathrm{rpm}$ with $500 \mathrm{rpm}$ increment. A T25/T28 turbocharger with compressor trim of 40 was installed to increase the $\mathrm{CNG}$ engine output performance. The inducer and exducer size of the turbocharger are 37.8 and $59.7 \mathrm{~mm}$ respectively. In this test, the CNG engine installed with stratified piston. Figure 2 shows the stratified piston with bowl shape geometry on its crown.

The CNG was stored at 3000 psi pressure in cascade tank and its pressure was reduced by pressure regulator before injected into the combustion chamber. The properties of the gasoline and CNG fuels are shown in Table 2 and composition of CNG used in this test is listed in Table 3. The mass flow rate of CNG was measured using gas flow meter. A pressure sensor (Kistler type 6125B) was installed in cylinder number 1 to record the inside cylinder pressure. Exhaust emissions were measured using EMS Model 5002 portable exhaust gas analyser.

\section{Experimental setup and procedures}




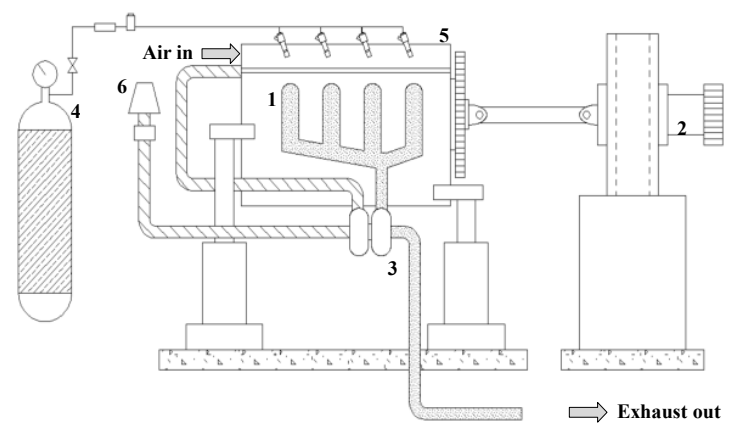

1. CNGDI engine

2. Eddy current dynamometer

3. Turbocharger

\section{CNG Tank}

5. Fuel injection rail

6. Air filter

Figure 1. Schematic of experiment setup.

Table 1. Specification of CNGDI engine.

\begin{tabular}{|l|c|}
\hline \multicolumn{1}{|c|}{ Engine Parameters } & Value \\
\hline Number of cylinder & 4 \\
\hline Displacement volume $\left(\mathrm{cm}^{3}\right)$ & 1596 \\
\hline Bore (mm) & 76 \\
\hline Stroke (mm) & 88 \\
\hline Compression ratio & $14: 1$ \\
\hline Connecting rod length $(\mathrm{mm})$ & 131 \\
\hline
\end{tabular}

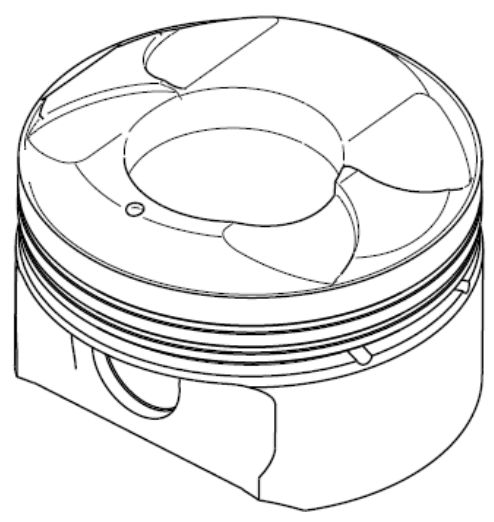

Figure 2. Stratified piston crown.

Table 2. Properties of gasoline and CNG fuels [6].

\begin{tabular}{|l|c|c|}
\hline \multicolumn{1}{|c|}{ Properties } & $\begin{array}{c}\text { Gasolin } \\
\text { e }\end{array}$ & CNG \\
\hline Specific gravity $\left(\mathrm{kg} / \mathrm{m}^{3}\right)$ & $\begin{array}{c}0.72- \\
0.78\end{array}$ & 0.72 \\
\hline $\begin{array}{l}\text { Heat of vaporization } \\
(\mathrm{KJ} / \mathrm{kg})\end{array}$ & 305 & 509 \\
\hline $\begin{array}{l}\text { Laminar burning velocity } \\
(\mathrm{m} / \mathrm{s})\end{array}$ & 0.43 & 0.50 \\
\hline $\begin{array}{l}\text { Higher heating value } \\
(\mathrm{MJ} / \mathrm{kg})\end{array}$ & 47.3 & 55.5 \\
\hline $\begin{array}{l}\text { Lower heating value } \\
(\mathrm{MJ} / \mathrm{kg})\end{array}$ & 44.0 & 50.0 \\
\hline
\end{tabular}

\begin{tabular}{|l|c|c|}
\hline Stoichiometric AFR & 14.6 & 17.23 \\
\hline Research octane number & $92-98$ & 120 \\
\hline
\end{tabular}

Table 3. Typical composition (vol. \%) of CNG [1].

\begin{tabular}{|c|c|c|}
\hline Component & Symbol & Volumetric (\%) \\
\hline Methane & $\mathrm{CH}_{4}$ & 94.42 \\
\hline Ethane & $\mathrm{C}_{2} \mathrm{H}_{6}$ & 2.29 \\
\hline Propane & $\mathrm{C}_{3} \mathrm{H}_{8}$ & 0.03 \\
\hline Butane & $\mathrm{C}_{4} \mathrm{H}_{10}$ & 0.25 \\
\hline Carbon Dioxide & $\mathrm{CO}_{2}$ & 0.57 \\
\hline Nitrogen & $\mathrm{N}_{2}$ & 0.44 \\
\hline Others & $\mathrm{H}_{2} \mathrm{O}+$ & 2.00 \\
\hline
\end{tabular}

\section{Results and discussions}

The performance of $\mathrm{CNG}$ engine with respect to brake power, brake torque, brake mean effective pressure, BSFC, FCE and exhaust emissions were examined for NA and force induction under several steady state conditions. Figure 3 and 4 present the results of brake power and brake torque at WOT for both NA and turbocharger $\mathrm{CNG}$ engine. On average, the increment of $26 \%$ in brake power can be seen throughout the speed range. The maximum brake power obtained by NA and turbocharged were $50 \mathrm{~kW}$ and $59 \mathrm{~kW}$ respectively both at $4500 \mathrm{pm}$. In the case of brake torque, maximum torque obtained by NA and turbocharged were $119 \mathrm{Nm}$ and 148 $\mathrm{Nm}$ respectively both at $3000 \mathrm{rpm}$. There is $24 \%$ of additional output at maximum torque. This is mainly due to the excess of oxygen available to convert the fuel energy to useful work.

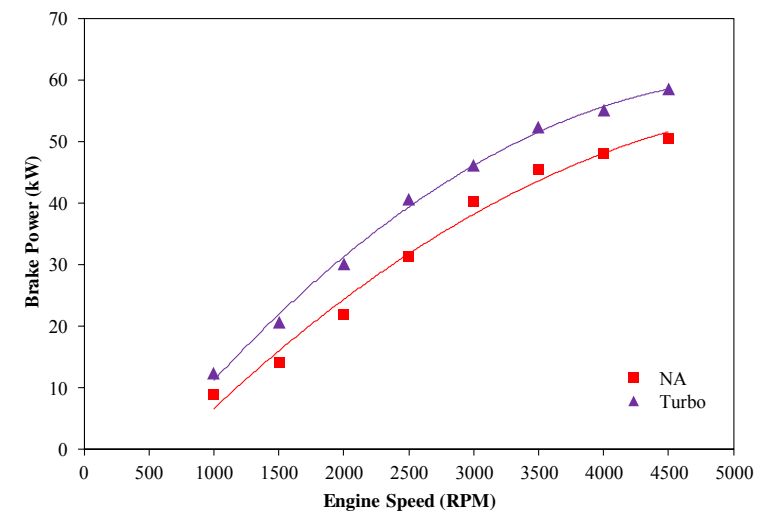

Figure 3. Brake power versus engine speeds. 


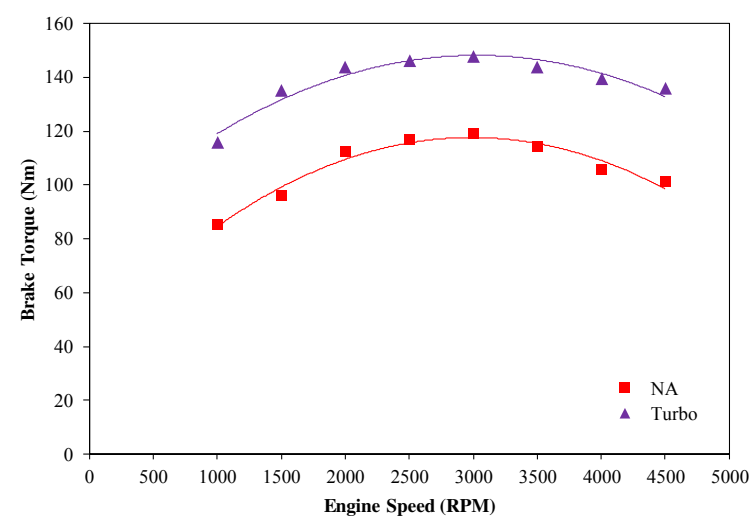

Figure 4. Brake torque versus engine speeds.

As shown in Figure 5, the BMEP of turbocharged is 8 $-18 \%$ higher than NA CNG engine. This is because higher intake pressure created by turbocharger increased peak pressure during compression stroke. Volumetric efficiency measured the maximum amount or air into the engine and higher volumetric efficiency increase the power output. There are $7-53 \%$ volumetric efficiency rise with turbocharged operation compared to NA as shown in Figure 6.

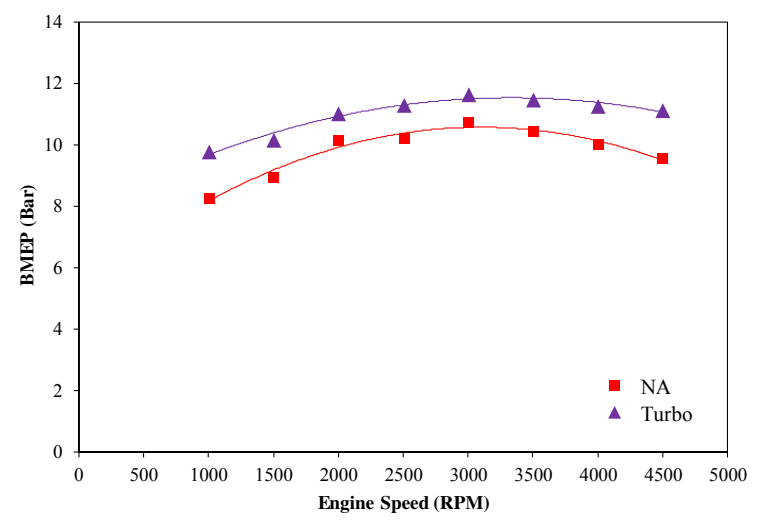

Figure 5. BMEP versus engine speeds.

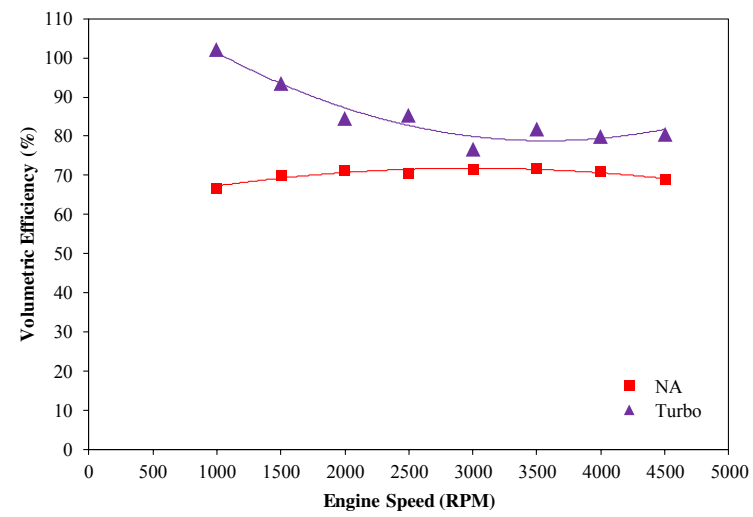

Figure 6. Volumetric efficiency versus engine speeds.

The BSFC curve in Figure 7 shows turbocharged results produced remarkably $3-20 \%$ lower fuel consumption compared to NA. The minimum BSFC of NA and turbocharged are $157 \mathrm{~g} / \mathrm{kW} \cdot \mathrm{h}$ and $130 \mathrm{~g} / \mathrm{kW} \cdot \mathrm{h}$ respectively both at $3000 \mathrm{rpm}$. Because of lower BSFC, turbocharged $\mathrm{CNG}$ engine achieves $3-22 \%$ higher FCE compare to NA as shown in Figure 8.

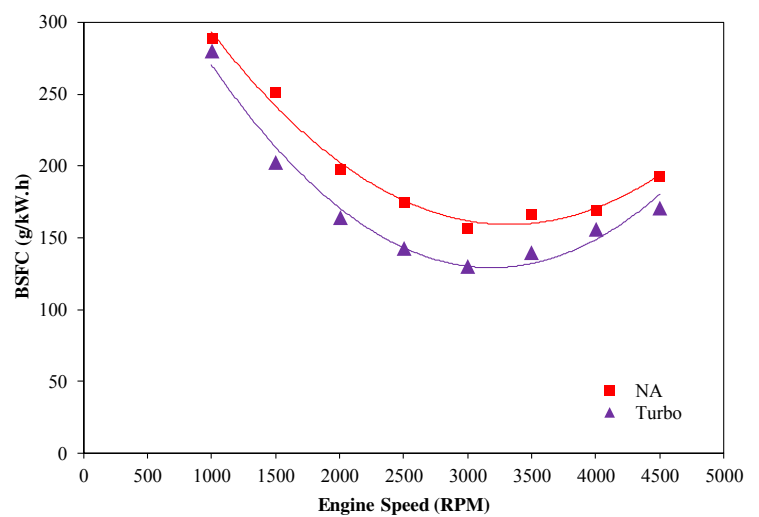

Figure 7. BSFC versus engine speeds.

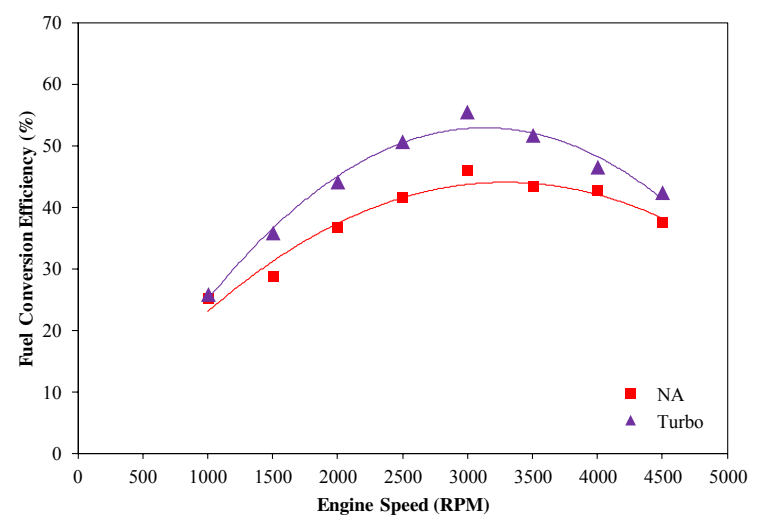

Figure 8. Fuel conversion efficiency versus engine speeds.

Figure 9 shows the Lambda value both NA and turbocharged. Generally, throughout the tested speed, both engine condition operated under lean mixture. The exhaust emission of $\mathrm{HC}$ for both NA and turbocharged are presented in Figure 10. It shows that $\mathrm{CNG}$ engine with turbocharger lower the unburned hydrocarbon emission compare to NA. The emission of $\mathrm{HC}$ is reduced by $3-15 \%$ with turbocharger due to a more complete combustion of CNG. Furthermore, it was found that $\mathrm{CNG}$ engine with turbocharger produced less $\mathrm{CO}, 14-25 \%$ in reduction compare to NA as shown in Figure 11.

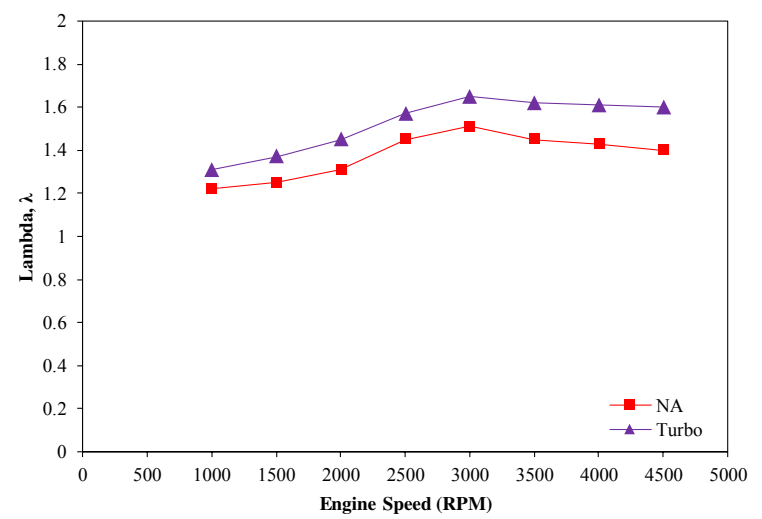

Figure 9. Lambda versus engine speeds. 


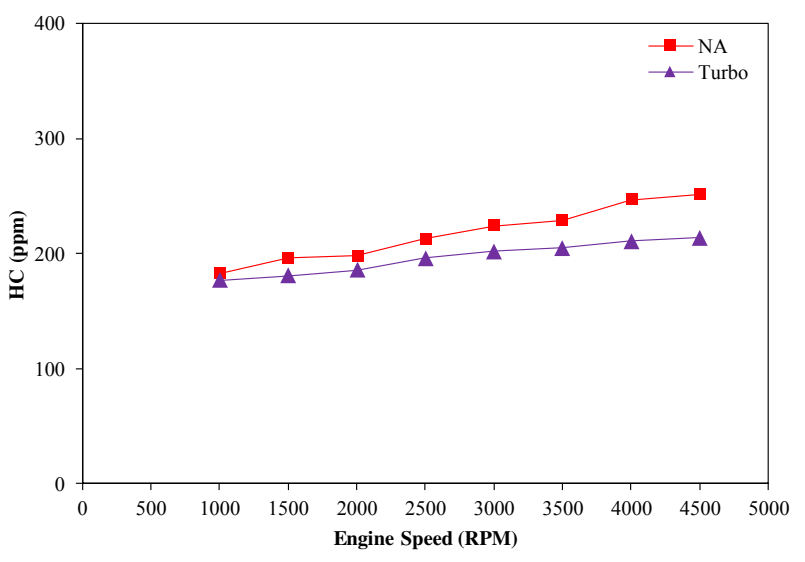

Figure 10. Hydrocarbon emission versus engine speeds.

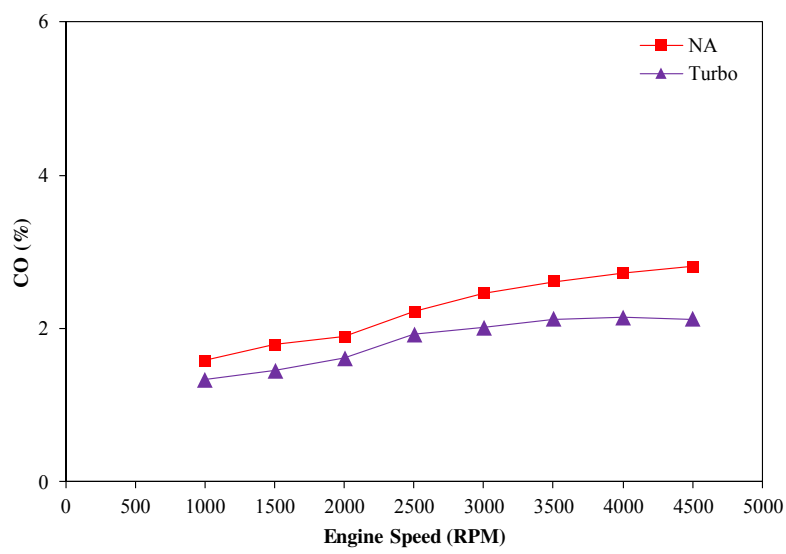

Figure 11. Carbon monoxide emission versus engine speeds.

Figure 12 shows the formation of $\mathrm{CO}_{2}$ emission on turbocharged is $5-17 \%$ higher compare to NA. This trend also true on $\mathrm{NO}_{\mathrm{x}}$ emission where turbocharged produced $7-29 \%$ higher compare to NA as shown in Figure 13. This higher formation of $\mathrm{NO}_{\mathrm{x}}$ in turbocharged engine is primarily cause by dissociation on $\mathrm{N}_{2}$ due to high combustion temperature, pressure and leaner mixture.

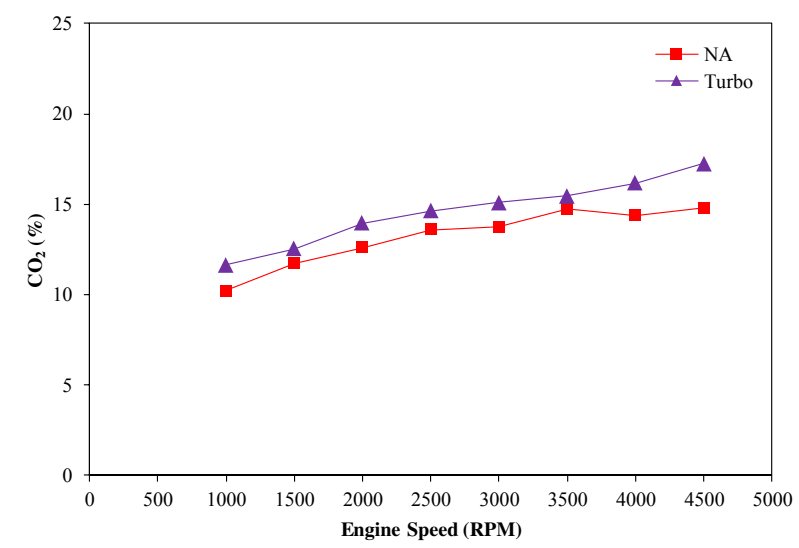

Figure 12. Carbon dioxide emission versus engine speeds.

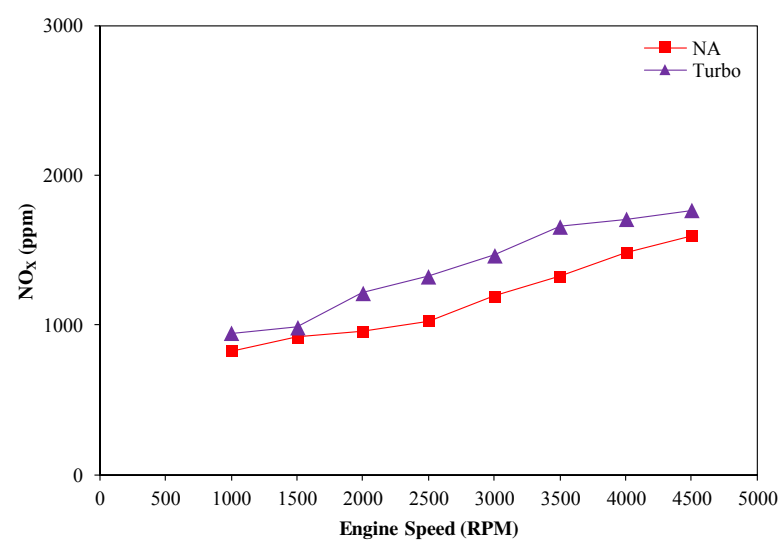

Figure 13. Nitrogen oxides emission versus engine speeds.

\section{Conclusion}

This study demonstrates that stratified charge CNG DI with turbocharger has a potential for higher engine output and improved fuel economy. The conclusion of these test are list as given below.

1. On average, $\mathrm{CNG}$ engine with turbocharger results $26 \%$ higher in brake power and $31 \%$ increment in brake torque.

2. Turbocharged $\mathrm{CNG}$ engine produced minimum BSFC of $130 \mathrm{~g} / \mathrm{kW} \cdot \mathrm{h}$ and $3-22 \%$ higher FCE compare to NA CNG engine.

3. Turbocharger improve volumetric efficiency of $\mathrm{CNG}$ engine by $7-53 \%$.

4. Emission of pollutant gaseous from NA CNG engine significantly reduced by application turbocharger with $3-15 \%$ reduction of unburned $\mathrm{HC}$ and $14-25 \%$ of $\mathrm{CO}$.

\section{Acknowledgement}

The authors would like to acknowledge to Ministry of Science, Technology and Innovation (MOSTI), Ministry of Higher Education Malaysia and Universiti Teknikal Malaysia Melaka (UTeM) for sponsoring the Ph.D study and research work under project 03-01-02 SF0995.

\section{References}

[1] M. A. Kalam and H. H. Masjuki, "An experimental investigation of high performance natural gas engine with direct injection" Energy 36, 3563-3571, (2011)

[2] S. Aljamali, S. Abdullah, W. M. F. Wan Mahmood and Y. Ali, "Effect of fuel injection timing on performance and emissions of stratified combustion CNGDI engine" Applied Thermal Engineering 109, 619-629, (2016)

[3] J. E. Kirwan, M. Shost, G. Rothn and J. Zizelman, "3-Cylinder turbocharged gasoline direct injection: A high value solution for Low $\mathrm{CO}_{2}$ and $\mathrm{NO}_{\mathrm{x}}$ emissions" SAE Technical Paper 2010-01-0590, (2010) 
[4] H. Zhao, Advanced direct injection combustion engine technologies and development Volume 1: Gasoline and gas engine (CRC Press, UK, 2010)

[5] G. T. Chala, A. R. A. Aziz and F. Y. Hagos, "Combined effect of boost pressure and injection timing on the performance and combustion of $C N G$ in a DI spark ignition engine" Int. J. of Automotive Technology 18, No. 1, 85-96, (2016)

[6] J. B. Heywood, Internal combustion engine fundamental (McGraw-Hill, New York, 1988) 